\title{
Gender Interview on Functional Design, Hedonist, Symbolic Benefits for Motorcycle Buying Decision
}

\author{
Umbas Krisnanto $^{1}$, Widya Riani Utami ${ }^{2}$ \\ ${ }^{1}$ Postgraduate School, Perbanas Institute, Jakarta, Indonesia \\ ${ }^{2}$ Master of Management, Perbanas Institute, Jakarta, Indonesia \\ Correspondence: Umbas Krisnanto, Postgraduate School, Perbanas Institute, Jakarta, Indonesia.
}

Received: March 5, 2018

doi:10.11114/bms.v4i2.3082
Accepted: March 23, $2018 \quad$ Online Published: March 29, 2018

URL: https://doi.org/10.11114/bms.v4i2.3082

\begin{abstract}
Automatic motorcycle purchases increase over time. The purpose of research to determine the cause of consumers buy automatic gear motorcycle (matic) whether because of price, design, or benefits (functional, hedonic, symbolic). To lead consumers more focused, conducted qualitative research using interviews to matic owners in 4 large cities are evenly distributed between male and female motorcycle buyers. The result is all respondents interviewed buy matic because of design. Functional benefits had already in accordance with manufacturer specified, hedonic benefits because it looks sporty, symbolic benefits because it comes with gender colors. Interesting designs make motorcycle owners buy without looking at prices as the main reference. Implications for management to produce matic many variants that buyers got more choice.
\end{abstract}

Keywords: design, functional benefits, hedonic, symbolic, gender

\section{Introduction}

\subsection{Research Problem}

As noted in the Central Bureau of Statistics (BPS), having a population with productive age (aged 15 years and over) has increased over the past 6 years. As shown in the following table,

Table 1. Labor force and labor force working age

Source: BPS

\begin{tabular}{c|c|c}
\hline Year & Work to labor force $(\%)$ & Labor force to working age (\%) \\
\hline 2012 & 93,87 & 67,76 \\
\hline 2013 & 93,83 & 66,67 \\
\hline 2014 & 94,06 & 66,60 \\
\hline 2015 & 93,82 & 65,76 \\
\hline 2016 & 94,39 & 66,34 \\
\hline 2017 & 94,50 & 66,67 \\
\hline
\end{tabular}

Gross Domestic Income (GDP) growth averaging 5.9\% per annum (2012-2017) where an average of 4.5\% of total GDP is itself sustained by the household consumption sector (BPS, 2017), then demographically and economy, working age population holds enormous market potential for the absorption of a consumer product.

Table 2. Household consumption and GDP growth

\begin{tabular}{c|c|c}
\hline \multirow{2}{*}{ Year } & \multicolumn{2}{|c}{ Growth } \\
\cline { 2 - 3 } & Household Consumption & Gross Domestic Product \\
\hline 2012 & 5,49 & 6,03 \\
\hline 2013 & 5,43 & 5,56 \\
\hline 2014 & 5,15 & 5.01 \\
\hline 2015 & 4,96 & 4,88 \\
\hline 2016 & 4,99 & 4,94 \\
\hline 2017 & 4,95 & 5,01 \\
\hline
\end{tabular}

Source: BPS

Improved purchasing power and the lack of adequate public transport facilities, it encouraged rapid growth of 
motorcycle sales in the last 6 years to reach the sales of automatic gear motorcycle (further called: matic) to reach an average of $68 \%$ of the total motorcycle market sales.

Table 3. Matic sales (2012 - 2017)

\begin{tabular}{c|c}
\hline Years & Matic sales (\%) \\
\hline 2012 & 57,59 \\
\hline 2013 & 63,04 \\
\hline 2014 & 67,33 \\
\hline 2015 & 75,39 \\
\hline 2016 & 87,80 \\
\hline 2017 & 95,60 \\
\hline
\end{tabular}

Source: AISI

Because of the potential of such a large motorcycle market then the competition among motorcycle manufacturers became very tight, especially in the motorcycle segment matic. Each motorcycle manufacturer will implement various strategies to win the competition. A company can run one of the two common pathways taken in order to be able to compete in a market that is by Differentiation or with Low Price. The combination of both strategies is even possible because many researchers conclude that customer value can be a surplus resulting from cost reduction. (Childers, et.al. 2001). Therefore, if a motorcycle manufacturer is able to provide a particular superior value to its product, such as from the design or price/value, it will be able to influence the customer's desire to buy because cost is still less than the benefit for customers compared to similar products. Design on a product becomes a differentiation as well as an identifier for a product to come to the fore especially on the market competition with many players. "Superior design distinguish products from competitors and help gain recognition in crowded marketplace". (Bloch, 2011). Actually Yamaha motorcycle manufacturers have been using this gender cues strategy on the promotion of its products that Mio since the beginning of the launch of motorcycle products in 2003 until now. Although Yamaha Mio is said to have won an award involving the women's assessment of the Kartini Brand Award, respectively during 2011-2013 (www.yamaha-motor.co.id.). The question then is whether the gender cues are successful campaigned in the promotion of its products or indeed its own consumers assume that the symbolic benefits of femininity that it offers is something interesting or important for the women users of these motorcycles. Furthermore, it becomes important then to consider whether the gender cues are adequately displayed on the promotional side only, or need to be symbolically displayed on the design of the product promotional course, or need to be displayed symbolically on the product design as a form of differentiation strategy of motorcycle products. And vice versa, it is also important to consider whether it is enough if the motorcycle design only presents the androgynous gender cues (impressing the same feminine and masculine level or Unisex) to gain a wider target audience. In addition to gender cues, Design in function as a symbol can also represent the impression of elegance, ease of use, young age, endurance and novelty or innovative in a new product. (Bloch, 2011). Therefore, it is very possible that for example the young age group will not buy motorcycles with a memorable design of parents or even people who are not young but still choose a motorcycle with a design that memorable young age as a symbol of himself is still included young age group. From a producer side, in this case motorcycle producers, providing more value on the design side, both as a symbol of quality, age and gender, is a dilemma as it often leads to increased production costs on the quality demands of materials used to display a product with designs that have high aesthetic value and lead to the addition of the selling price that tends to place the product with a design that is considered good in the upper segment and less attention to the segment below. Though the lower segment is a segment with the largest market where Yamaha Mio with lower middle price segmentation (under Rp.15,000,000) has dominated $52 \%$ automatic motorcycle market in Indonesia. (www.aisi.co.id.). Therefore, the right combination of design preferences with all its benefits (functional, hedonic, symbolic) with the selling price is needed to avoid over-design or over-price risks.

Problem Formulation. Given the increasingly tight competition motorcycle sales especially for low-end type of matic segment then the issues discussed in this study are: Which benefits are strongest influence consumer buying decisions among the three benefits in Design (Functional, Hedonic, Symbolic) on matic products in a gender manner?

\subsection{Problems Limitations}

Among the various product attributes, the author will only examine the design problem and its effect on the decision to buy by gender.

\subsection{Research Objectives}

In order for those engaged in the field of motorcycle industry to use this research as a reference to understand what are the most important benefits in motorcycle design and the relationship between Design and buying desire in consumer perception so that their products can have a higher value of money for consumers in terms of gender. 


\subsection{Previous Research}

Chung Shih Huang (2014), examines the relationship between consumer preferences with motorcycle product design in Taiwan with functional, communicative and aesthetic perspectives. In the study, it was concluded that the functional benefits of motorcycle designs were most strongly influenced in the selection of motorcycle models among students.

Lieven et.al (2014) examined the relationship between brand gender and brand equity in consumer goods, furniture and electronics products in Germany, and concluded that products with clear gender gestures (more feminine or masculine) would be easier to categorize, giving more positive and more customer-selected responses than products with less obvious gender cues.

Polyakova (2013), examines the relationship of packaging design as a marketing tool and fosters the desire to buy. The aim of the study was to examine consumer perceptions on different design elements on a milk pack and to inform the company of consumer interest and the importance of design attributes from a consumer point of view in Finland. In that study, it was concluded that packaging design became the main determinant to grow the buying desire.

Ehrnberger (2012), examined gender relationships with designs on prototypes of household electronic products namely Mega Hurricane Mixer and Dolphia Drill in Sweden. This research departs from a drill product message that is considered a masculine hand tool and only used by men while a blender is considered a feminine tool and is only used by women as a household utensil. Dolphia Drill is identified as a drill for women and is considered insufficient for larger drilling work. While Mega Hurricane Mixer is identified as a more powerful blender / mixer than a mixer commonly used as a household utensil. By exchanging their product messages, it can be seen how gender values are related in each design and product. Design is not only an end product but is associated in a social process between users, products and society.

Horvath (2001), examines the role of design in consumer ratings of mobile phone products in Budapest, Hungary. The purpose of the research is to explore the impact of product design on the buying decision process and its assessment-consumer ratings on the product. In the study, it was concluded that product designs determine consumer choice. The more common the product design is displayed, the more functional the impression consumers will receive. Aesthetic and hedonic values become less considered. Conversely, the newer and unusual designs are displayed the less functional the impression consumers receive. Aesthetic and hedonic values become more considered by consumers.

In another study, although it does not directly refer to customer value research on motorcycle users, that on Customer Value / Customer Value there are 3 components, namely: Functional Value (e.g. quality, performance, innovation, impression, price). Social Value (example: personal identity / personalization). Emotional Value (e.g. customer service). (Wu, 2016).

\subsection{Research Framework}

In this case, the frame of thought is that the purchase of a motorcycle is not just a purchase of goods or products that have functional value as a means of transportation but also have social values as a tool to identify his personality in society. These values tend to be stronger in people in big cities who are very concerned about what other people do as well as everyone trying to keep others' judgments on themselves. A motorcycle purchase decision will be worth as a self-appreciation or personal actualization in the eyes of the public. For motorcycle manufacturers, in addition to the functional value of a motorcycle itself, they must think of ways to meet the needs of the social values mentioned above, including their emotional values that are responses or ratings from motorcycle customers to the product they. Although the accuracy of decision-making is not appropriate but when customers realize that a product they buy is to satisfy the desire for the physical product as well as the hedonic desire of the users of the product then they will feel more comfortable with the purchase behavior is impulsive / and immediately. (Saad \& Metawie, 2015). By the time that happens, the motorcycle customers will more often make a purchase because every new products of motorcycles will have all the values sought by their customers to satisfy their 'physical' needs as well as their social and emotional needs, whose purchasing decisions are made quickly. Therefore, motorcycle design as one of the important product attributes in consumer buying decision, it is naturally made to be able to provide benefits not only in the function of vehicle and driving pleasure, but also symbolic benefits as the expression of the user's personality.

In this research will be explored and searched questions on the things below:

1. Which benefits most strongly influence consumer buying decisions among the three benefits in Design (Functional, Hedonist, Symbolic) on a matic?

2. Is a strong functional message related to gender in the decision to buy a matic?

3. Is there a strong hedonistic message related to gender in the decision to buy a matic?

4. How does the symbolic message-based design influence the price and the decision to buy a matic based on gender? 


\section{Research Method}

The type of this research is exploratory-descriptive-qualitative research. Qualitative research is a study that produces descriptive data in the form of written or oral words of people and behavior that can be observed. Descriptive data are obtained from the exploration of information from the informants / informants that have been processed and analyzed. The design of this qualitative research is divided into four stages:

1. Planning, which consists of determining the time of research, place of study and the preparation of research instruments.

2. Implementation. At this stage the researcher as the executor of research at once as a human instrument that seeks data information, i.e. interviews depth to the specified sources.

3. Data Analysis. This stage is done after the researcher conducted the interview depth to the resource person.

4. Findings, Conclusions and Recommendations. At this stage, all data from interviews that have been analyzed are summarized to answer the problem and provide recommendations for further research.

The selected research location is Jakarta as the heterogeneous country's capital city of all regions in 4 major cities. To strengthen the data, the interview was also conducted by phone (phone interview) to the resource persons who reside in Jakarta, Bandung, Semarang, \& Surabaya, which is considered to represent the region with the largest motorcycle market share in 4 major cities. The data are sourced from the in-depth interviews of the speakers either directly (face to face) in Jakarta, or by phone (phone interview) in Bandung, Semarang and Surabaya. To prevent bias, the resource used in this study is made according to the following criteria:

1. It is the main user of automatic motorcycle in its daily activities.

2. It is the main decision maker when buying a motorcycle.

3. Consider motorcycle design as one of the top three priorities when deciding to buy.

4. The ratio of the number of male and female informants is 1: 1

\subsection{Interview Guidelines}

In this study, interview guidelines were created so that the results obtained can focus on the answer to the problem and have the same opening questions at each study site. Then, also used semi structured interview method, that is interview which begins with some specific question, but open to develop along with the way of interview (open-ended question). The proposed opening questions will include 3 things: Data Screening (Resource Selection), Resource Profile Data (personal data) and Interview Data (data focusing on matters relating to the motorcycle according to research objectives).

\subsection{Data Screening (Selection of Resources)}

a. Resources should be the main users of matic in their daily activities. Ownership of motorbikes may be on behalf of other family members.

b. The resource person must be the ultimate decision maker when purchasing the motorcycle. The resource person must be the person who really wants the motorcycle model.

c. Resources should consider motorcycle design as one of the top three priorities when deciding to buy.

\subsection{Interview Data}

a. Data 3 main reasons in choosing a motorcycle model now.

Possible answers are designs (including motor and color sizes), features, brand impression and model reputation.

b. If choosing a design as the main reason to buy a motorcycle now, then the question will continue to be developed with the concept of $5 \mathrm{~W}$ (why, why, why, why, why) by focusing on 3 design benefits. Functional: Is the motorcycle design an impressive high functional side like being comfortable driving in any field or can carry lots of goods and passengers?

Hedonist: Does the design of the motorbike impress a high hedonic side like being comfortably driven in high-speed adrenaline rush, or being driven out of town or easily customized?

Symbolic: Is the motorcycle design an impressive symbolic side that represents the wearer? For example that the motorcycle was chosen because the design that seemed suitable for women or young children. Furthermore, what kind of impressive shape is also impressed on the motorcycle.

c. The influence of the design that symbolically impressed the price and the decision to buy the motorcycle. The question form can be a presupposition, for example in female resource, if when buying first, your motorcycle with the 
same price and specification as the present but with motorcycle design like any other motorcycle that you think masculine / feminine, will you still buy it? If you still want a memorable woman or feminine, do you mind if the price becomes more expensive? Why?

\subsection{Data Analysis Techniques}

Data analysis is a process of systematically compiling data obtained from interviews by organizing data into categories or units, organizing into patterns, choosing which ones are important and that will be learned, and making conclusions so easily understood by oneself and people other.

There are 3 components in the data analysis:

1. Data reduction. Since the data obtained from the interviews are numerous, it is necessary to record carefully and in detail. From the detailed data, it is then reduced by summarizing, selecting the important points that answer the subject and searched for the similarities of the theme and pattern.

2. Presentation of Data. The presentation of qualitative research data is done in the form of exposure and chart of relationships between categories.

3. Data verification and inference. Initial conclusions can be obtained from the interview data in Jakarta is still temporary, and then become a credible conclusion if found valid and consistent data in the next city of Bandung, Semarang and Surabaya.

\subsection{Testing Data Credibility}

To test the credibility of this qualitative research data, researchers used the Triangulation technique. Triangulation technique is to capture data with various methods and by crossing the information obtained so that the data obtained more complete from various points of view. After getting the data that is saturated information obtained from data sources have the same then the data obtained more credible. In this study, will be compared information obtained from the resource persons.

\section{Research Results}

\subsection{Interview Results}

\begin{tabular}{|c|c|c|c|}
\hline Question & Details & Men & Women \\
\hline \multirow{6}{*}{ Reason to buy } & Design & 18 & 18 \\
\hline & Fuel saving & 7 & 2 \\
\hline & Affordable price & 4 & 1 \\
\hline & Trusted brand & 2 & 3 \\
\hline & Feature & 2 & 2 \\
\hline & Engine performance & 2 & 2 \\
\hline \multirow{4}{*}{ Functional design benefit } & Small light \& sleek comfortable & 4 & 10 \\
\hline & Appropriate posture & 2 & 10 \\
\hline & Lively on the street and alley & 3 & 5 \\
\hline & Enough for passengers & 2 & 0 \\
\hline \multirow{8}{*}{ Hedonic design benefits } & Simple & 8 & 8 \\
\hline & Modern & 8 & 6 \\
\hline & Sporty & 6 & 4 \\
\hline & Unisex & 2 & 4 \\
\hline & Difference & 3 & 1 \\
\hline & Elegant & 1 & 3 \\
\hline & Dynamic & 2 & 0 \\
\hline & Proportional front rear & 1 & 0 \\
\hline \multirow{5}{*}{ Symbolic design benefits } & Feminine/masculine color & 3 & 7 \\
\hline & Youth color & 2 & 1 \\
\hline & Unisex riding & 1 & 0 \\
\hline & Stump and stout & 1 & 0 \\
\hline & Elegant & 0 & 1 \\
\hline \multirow{2}{*}{ Willing to pay more? } & Yes & 17 & 10 \\
\hline & No. & 1 & 8 \\
\hline
\end{tabular}

\section{Discussion}

The reason to buy matic is the design is the biggest opinion of respondents is in accordance with the development of research 15 years (Bloch, 2011). 
Benefits of automatic motor functional design is appropriate posture, small size and light, agile on the road, ride with passengers, lean through the alley and parking, comfortable driving, protect splashes. The result of the interview is in accordance with Dunbar et.al (2017). The benefits of hedonism: a pleasure in sporty impression (Snelders, et.al 2014), simple, non-market and new, modern and unisex, elegant and rounded impression, dynamic impression, not many ornaments, bright, not tacky, front rear proportional size, shape. Symbolic benefits: unisex color (Ehrnberger, 2012), the color of the young, sturdy and handsome.

Price: agree plus the design will raise the price, the price is too expensive. (Tornberg et.al, 2002). Products by gender are preferred by consumers (Simpson, et.al, 1996).

\section{Conclusions}

1. Consumers buy motor more interested because of its design.

2. The functional benefits offered by the manufacturers are in accordance with consumer demand.

3. The hedonic benefits that consumers consider to be the second attraction after the functional benefits that manufacturers offer.

4. Symbolic benefits support both previous benefits that have not been displayed by the manufacturer.

5. Price becomes second condition after producers succeeded in displaying the three benefits become main choice of consumer.

\section{Managerial Implications}

1. To add consumer interest in addition to design, manufacturers should display variants that suggest other factors

2. To add functional benefits should manufacturers meet the opinions of consumers to freely add passengers.

3. To add hedonist benefits should the manufacturer add to the luxury.

4. To add symbolic benefits should manufacturers give the impression of elegance in riding.

5. Price is not the main thing for consumers, manufacturers can add various features in accordance with the market desire.

6. For male consumers, manufacturers can add masculine features and vice versa.

\section{References}

Bloch, P. H. (2011). Product Design and Marketing: Reflections After Fifteen Years. Journal of Product Innovation Management, 28(3), 378-380. https://doi.org/10.1111/j.1540-5885.2011.00805.x

Childers, T. L., Christopher, L. C., Joann, P., \& Stephen, C. (2001). Hedonic and utilitarian motivations for online retail shopping behavior. Journal of Retailing, 77, 511-535. https://doi.org/10.1016/S0022-4359(01)00056-2

Crilly, N. (2011). Do users know what designers are up to? Product experience and the inference of persuasive intentions. International Journal of Design, 5(3), 1-15.

Dunbar, R. I. M., Jacques, L., Rafael, W., Cole, R., Eiluned, P., James, C., \& Pádraig, M. C. (2017). Functional Benefits of (Modest) Alcohol Consumption. Adaptive Human Behavior and Physiology, 3, 118-133. https://doi.org/10.1007/s40750-016-0058-4

Ehrnberger, K. (2012). Visualising Gender Norms in Design: Meet the Mega, Hurricane Mixer and the Drill Dolphia, International Journal of Design, 6(3). www.ijdesign.org/ojs/index.php/IJDesign/article/view/1070/53

Horvath, D. (2001). The Role of Product Design in Product Related Consumer Judgements, Dissertation, University of Budapest, Hongaria, http://phd.lib.uni-corvinus.hu/635/2/Horvath_Dora_den.pdf

http://www.aisi.or.id/

http://www.yamaha-motor.co.id/archive/news/2013/07/346

Lieven, T. (2014). The effect of Brand Gender on Brand Equity. Psychology \& Marketing journal, 31. https://doi.org/10.1002/mar.20701

McFarlane, D. A. (2013). The Strategic Importance of Customer Value. Atlantic Marketing Journal, 2(1).

Polyakova, K. (2013). Packaging design as a Marketing tool and Desire to purchase, Thesis, University of Saimaa, Finlandia. http://publications.theseus.fi/bitstream/handle/10024/55293/Polyakova_Ksenia.pdf?sequence=1

Saad, M., \& Madiha, M. (2015) Store Environment, Personality Factors and Impulse Buying Behavior in Egypt: The Mediating Roles of Shop Enjoyment and Impulse Buying Tendencies. Journal of Business and Management 
Sciences, 3(2), 69-77. http://pubs.sciepub.com/jbms/3/2/3 DOI:10.12691/jbms-3-2-3

Shih, H. C. (2014). An Investigation of the Relation between Consumers' Preference and Motorcycle Product Design A Case Study of Chienkuo Technology University Students. Journal of Convergence Information Technology, 9(6).

Simpson, P. M., Steve, H., \& Gene, B. (1996). Male Nudity in Advertisements: A Modified Replication and Extension of Gender and Product Effects. Journal of the Academy of Marketing Science, 24(3), 257-262. https://doi.org/10.1177/0092070396243006

Snelders, D., Ruth, M., \& Maartje, H. (2014). Using Social Distinctions in Taste for Analysing Design Styles across Product Categories. International Journal of Design, 8(3), 23-34.

Tornberg, K., Miikka, J., \& Jari, P. (2002). Activity-based costing and process modeling for cost-conscious product design: A case study in a manufacturing company. Int. J. Production Economics, 79(75), 82. https://doi.org/10.1016/S0925-5273(00)00179-1

Wu, S. I., \& Hui, L. C. (2016). The Model of Relationship between the Perceived Values and the Purchase Behaviors toward Innovative Products. Journal of Management and Strategy, 7(2). https://doi.org/10.5430/jms.v7n2p31

Zhao, L., Changwei, W., Xiaohui, P., Bin, L., \& David, A. (2017). The Pricing Strategy of Oligopolistic Competition Food Firms with the Asymmetric Information and Scientific Uncertainty. Journal of Food Quality, Article ID 4628905, 14 pages. https://doi.org/10.1155/2017/4628905

\section{Copyrights}

Copyright for this article is retained by the author(s), with first publication rights granted to the journal.

This is an open-access article distributed under the terms and conditions of the Creative Commons Attribution license which permits unrestricted use, distribution, and reproduction in any medium, provided the original work is properly cited. 